\title{
Nitrogen-Decreasing and Yield-Increasing Effects of Combined Applications of Organic and Inorganic Fertilizers under Controlled Irrigation in a Paddy Field
}

\author{
Yuanyuan Li ${ }^{1,2}$, Xiaohou Shao, ${ }^{1 *}$, Wenlu Guan', ${ }^{1,}$ Liang Ren ${ }^{3}$, \\ Jie Liu ${ }^{3}$, Jinlan Wang ${ }^{4}$, Qijin Wu ${ }^{4}$ \\ ${ }^{1}$ Key Laboratory of Efficient Irrigation-Drainage and Agricultural Soil-Water Environment in Southern China, \\ Hohai University, Nanjing 210098, P.R. China \\ ${ }^{2}$ College of Water Conservancy and Hydropower, Hohai University, Nanjing 210098, P.R. China \\ ${ }^{3}$ Bureau of Comprehensive Development Ministry of Water Resources, Beijing 100053, P.R. China \\ ${ }^{4}$ Water Affairs Bureau in Gaochun County, Nanjing 211300, P.R. China
}

Received: 14 December 2015

Accepted: 21 January 2016

\begin{abstract}
Inadequate fertilization may result in water pollution and nutrient leaching, especially in paddy fields. It is expected that the combination of organic and inorganic fertilizers reduces water pollution in addition to crop yield improvement. In this study, combined fertilization with organic and inorganic fertilizers was tested under controlled irrigation conditions. With the addition of organic fertilizer, the $\mathrm{pH}$ of paddy soil could be maintained in a rather neutral environment, and the soil organic matter concentration could increase especially under a controlled irrigation regime. Hydrolyzed nitrogen was noticed in the fertilized plots with an increasing trend compared to unfertilized plots. However, available phosphorus concentration decreased in all treatments after rice harvest. During the drainage process, the ammonium nitrogen was the main form of nitrogen loss. Organic fertilizer application significantly improved productive panicles and thus increased paddy yield. We concluded that with the combination of organic-inorganic fertilizer application and controlled irrigation, the pollutants can be removed to some extent and the rice yield can be increased significantly, which is favorable for environmental protection and yield promotion.
\end{abstract}

Keywords: rice, organic fertilizers, soil, environment, pollution

\section{Introduction}

Studies have suggested that adequate fertilization is important for healthy plant growth with high crop

*e-mail: shaoxiaohou@163.com yield; otherwise many nutrients would be lost from the soil $[1,2]$. In this regard, a combination of organic and inorganic fertilizers could be a possible remedy for yield improvement and avoiding environmental pollution, especially in paddy fields. Recent reports have revealed the effect of fertilizers on rice yield, soil fertility, soil 
porosity, soil structure, and underground water pollution through efficient use of nitrogen [3, 4]. The proper rate of organic fertilizer increases fertilizer use efficiency in addition to improvement in productivity [5-9]. This is mainly because of quick hydrolysis of chemical fertilizer compared to slow nutrient release in organic fertilizer to recover soil fertility and soil productivity [10-12]. With the addition of organic matter in soil, the plants are able to uptake nitrogen efficiently and resolve soil acidification [13-16]. It is a fact that nutrients contained in organic manures are released more slowly and are stored for a longer time in the soil, thereby ensuring a long residual effect [17-20]. Complementary use of organic manure and mineral fertilizers has proven to be a sound method in soil fertility management in many countries [21-24].

Most research in recent years has focused on nitrogen fertilizer use efficiency in relation to rice growth and yield, but the environmental benefits from organic fertilizer application were rarely reported, especially under controlled irrigation conditions. This paper is more informative on nitrogen decreasing through the beneficial effect of combined application of organic and inorganic fertilizers through improvements in soil physical and chemical properties and, ultimately, rice yield.

\section{Materials and Methods}

\section{Experimental Site}

The experiments were carried out at the Vegetables (Flowers) Scientific Institute, (latitude $32^{\circ} 13^{\prime} \mathrm{N}$, longitude $119^{\circ} 04^{\prime} \mathrm{E}$ ), Hengxi Town of Nanjing, Jiangsu Province in China during the 2013 rice-growing season. The experimental site is located in a subtropical humid region, with an average annual rainfall of 1,106.5 mm - mostly in the rainy season from the end of June to the middle of September. Average annual evaporation was 1,472.5 mm, annual sunshine was 2,017.2 h, average annual temperature was $15.7^{\circ} \mathrm{C}$, maximum average humidity was $81 \%$, and average wind speed was $19.8 \mathrm{~m} / \mathrm{s}$.
Pre-experiment analysis showed that paddy field soil was clayey loam with $\mathrm{pH} 5.87$, bulk density $1.35 \mathrm{~g} \mathrm{~cm}^{-3}$, field capacity $28 \%$, organic matter $21.7 \mathrm{~g} \mathrm{~kg}^{-1}$, hydrolyzed nitrogen $86.5 \mathrm{mg} \mathrm{kg}^{-1}$, and available phosphorus $25.3 \mathrm{mg}$ $\mathrm{kg}^{-1}$ at the $0-60 \mathrm{~cm}$ soil layer.

\section{Experimental Design}

Paddy rice (Oriza sativa L. cv. Kaohsiung 139) was grown in completely randomized blocks with sub-plot size as $10 \mathrm{~m}^{2}$ under two irrigation regimes, controlled irrigation (T1) and conventional irrigation (T2), fertilized at three levels: organic fertilizer + inorganic fertilizer (S1), inorganic fertilizer (S2) alone, and unfertilized control (S3). All the treatments were replicated three times. Each plot received separate irrigation water, drainage, water meter, and lysimeter, while all the plots shared one rain gauge. Polyethylene sheets were used around the bunds of each plot to prevent lateral seepage loss.

Controlled irrigation technology is a kind of watersaving irrigation technology [25-27]. Based on the formal experience, the ratio of organic fertilizer and chemical fertilizer was chosen as 4:6 with consideration of the same total nitrogen concentration received by paddy fields. Both of the basal fertilizers (during transplanting) and tillering fertilizer (about 30 days after transplanting) were applied with a compound fertilizer and panicle fertilizer (about 60 days after transplanting) was urea. The water and fertilizer design in the whole growth stage of paddy rice is shown in Table 1.

\section{Indicators and Measurements}

The pre and post experimental soil samples were collected from the $0-40 \mathrm{~cm}$ soil layer. The samples were air dried, ground, and passed through a $1 \mathrm{~mm}$ sieve. Soil $\mathrm{pH}$ was measured by a $\mathrm{pH}$ meter, organic matter by potassium dichromate volumetric method, total nitrogen by semimicro Macro Kjeldahl method, hydrolysis of nitrogen by hydrolysis diffusion method, total phosphorus and available phosphorus by molybdenum blue colorimetric

Table 1. Experimental design.

\begin{tabular}{|c|c|c|c|c|c|c|c|c|}
\hline \multirow{3}{*}{ Factor } & \multirow{3}{*}{ Level } & \multicolumn{7}{|c|}{ Practice at different growth stages } \\
\hline & & \multirow{2}{*}{ Green-up } & \multicolumn{3}{|c|}{ Tillering } & \multirow{2}{*}{$\begin{array}{l}\text { Jointing- } \\
\text { Booting }\end{array}$} & \multirow{2}{*}{$\begin{array}{l}\text { Heading- } \\
\text { Flowering }\end{array}$} & \multirow{2}{*}{ Milking } \\
\hline & & & Early & Middle & Late & & & \\
\hline \multirow{2}{*}{ Irrigation } & Controlled & $100 \%(5-25)$ & $\begin{array}{c}70 \% \\
(0-50)\end{array}$ & $\begin{array}{c}65 \% \\
(0-50)\end{array}$ & $\begin{array}{l}60 \% \\
(0-0)\end{array}$ & $\begin{array}{c}80 \% \\
(0-70)\end{array}$ & $\begin{array}{c}80 \% \\
(0-70)\end{array}$ & $\begin{array}{c}65 \% \\
(0-20)\end{array}$ \\
\hline & Conventional & $100 \%(30-50)$ & $\begin{array}{l}100 \% \\
(0-30)\end{array}$ & $\begin{array}{c}100 \% \\
(15-30)\end{array}$ & $\begin{array}{l}60 \% \\
(0-0)\end{array}$ & $\begin{array}{c}100 \% \\
(30-50)\end{array}$ & $\begin{array}{c}100 \% \\
(30-50)\end{array}$ & $\begin{array}{c}100 \% \\
(15-30)\end{array}$ \\
\hline \multirow{3}{*}{ Fertilizer } & Combined & $54+81$ & \multicolumn{3}{|c|}{$16.24+24.36$} & $23.2+34.8$ & & \\
\hline & Chemical & $0+135$ & \multicolumn{3}{|c|}{$0+40.6$} & $0+58$ & & \\
\hline & No-fertilizer & 0 & \multicolumn{3}{|c|}{0} & 0 & & \\
\hline
\end{tabular}

Notes: 1) The first number of the irrigation line is a percentage of the saturated water content of soil; 2) numbers in parenthesis are ranges of the storage depths of surface water in $\mathrm{mm}$ in the paddy field; and 3) the number in fertilizer line is the total nitrogen amount of organic fertilizer and chemical fertilizer in $\mathrm{kg} \mathrm{hm}^{-2}$ in the paddy field. 
method, and total potassium and available potassium by flame photometry [28, 29].

During the tillering period we determined concentrations of total nitrogen (TN), ammonium nitrogen $\left(\mathrm{NH}_{3}-\mathrm{N}\right)$, and nitrate nitrogen $(\mathrm{NO}-\mathrm{N})$ in the surface and drained water before and after fertilization. $\mathrm{TN}$ was measured by potassium persulfate oxidation and ultraviolet spectrophotometry, $\mathrm{NH}_{3}-\mathrm{N}$ by Nessler reagent, and NO-N by ultraviolet spectrophotometry following the procedures of SEPA [30]. The yield components viz. panicle number, kernel weight, and kernel number per panicle were determined in a sample area of $1 \mathrm{~m}^{2}$.

\section{Statistical Analysis}

Data was statistically analyzed using analysis of variance with SPSS statistical software. The mean differences among treatments were analyzed through Duncan's Multiple Range Test. The variance homogeneity of the ANOVA was tested before ANOVA analysis [31].

\section{Results and Discussions}

\section{Soil pH and Organic Matter}

As shown in Table 2, all the $\mathrm{pH}$ values increased and were very close to neutral after rice harvest. The irrigation and fertilizer all showed no significance on $\mathrm{pH}$ before fertilization. It was illustrated that organic fertilizer and conventional irrigation could maintain the paddy soil in a rather neutral environment. It was also obvious that $\mathrm{pH}$ values varied much more under combined fertilizer compared to the other two fertilizer treatments, illustrating that organic fertilizer could adjust soil acidity, which was significant for crop growth.

Soil organic matter concentration increased after rice harvest in all fertilized treatments in comparison with those before steeping field, except for no fertilizer treatments. Soil organic matter concentration in controlled irrigation was higher than that in conventional irrigation for the combined fertilizer treatment, while it was opposite for inorganic fertilizer. It meant that in controlled irrigation more organic matters were retained in the soil than that in conventional irrigation, which could result in high rice yield. Thus we could promote rice yield through a combination of controlled irrigation with organic fertilization based on the results obtained above. The fertilizer factor was extremely significant on organic matter after fertilization, and the interaction between irrigation and fertilizer was also significant compared to before fertilization.

\section{Soil Chemical Properties}

As shown in Table 2, concentrations of both total nitrogen (TN) and total phosphorus (TP) increased after rice harvest in all treatments. Under two irrigation regimes, TN and TP showed the same increasing pattern as combined $>$ inorganic $>$ no-fertilizer with different magnitudes. The main reason for such a pattern might be that organisms in organic fertilizer were favorable for TN and TP settlement, which was consistent with the results obtained above. From Table 2 the fertilizer effect on TN and TP contents was significant both before and after fertilization, while irrigation and the interaction between irrigation and fertilizer showed no significance on TN. As for irrigation effect on TP, it was not consistent before and after fertilization.

Hydrolyzed nitrogen concentration increased in both combined and inorganic fertilizer treatments, while it declined in no-fertilizer treatment. This illustrated that fertilization alone can effectively increase hydrolyzed nitrogen concentration under both irrigation conditions. The average hydrolyzed nitrogen concentration was $83.25 \mathrm{mg} \mathrm{kg}^{-1}$ in combined fertilizer treatment and

Table 2. Soil properties in different treatment plots before and after fertilization.

\begin{tabular}{|c|c|c|c|c|c|c|c|c|c|c|c|c|c|}
\hline \multicolumn{2}{|c|}{ Treatment } & \multicolumn{2}{|c|}{$\begin{array}{c}\mathrm{pH} \\
\left(\mathrm{H}_{2} \mathrm{O}\right)\end{array}$} & \multicolumn{2}{|c|}{$\begin{array}{l}\text { Org Matter } \\
\left(\mathrm{g} \mathrm{kg}^{-1}\right)\end{array}$} & \multicolumn{2}{|c|}{$\begin{array}{l}\text { Total N } \\
\left(\mathrm{g} \mathrm{kg}^{-1}\right) \\
\end{array}$} & \multicolumn{2}{|c|}{$\begin{array}{l}\text { Total P } \\
\left(\mathrm{g} \mathrm{kg}^{-1}\right) \\
\end{array}$} & \multicolumn{2}{|c|}{$\begin{array}{l}\text { Hydrol N } \\
\left(\mathrm{mg} \mathrm{kg}^{-1}\right)\end{array}$} & \multicolumn{2}{|c|}{$\begin{array}{l}\text { Available P } \\
\left(\mathrm{mg} \mathrm{kg}^{-1}\right)\end{array}$} \\
\hline Irrigation & Fertilizer & Bef & Aft & Bef & Aft & Bef & Aft & Bef & Aft & Bef & Aft & Bef & Aft \\
\hline Controlled & Combined & 6.10 & 6.90 & 19.2 & 30.0 & 0.62 & 0.89 & 0.35 & 2.49 & 75.1 & 84.0 & 18.3 & 16.9 \\
\hline Controlled & Inorganic & 6.10 & 6.82 & 19.5 & 24.4 & 0.60 & 0.66 & 0.46 & 2.23 & 76.0 & 90.4 & 18.9 & 16.4 \\
\hline Controlled & No-fertilizer & 6.10 & 6.79 & 19.5 & 16.0 & 0.63 & 0.68 & 0.37 & 2.03 & 78.0 & 66.9 & 19.0 & 15.6 \\
\hline Convention & Combined & 6.12 & 7.00 & 19.0 & 27.0 & 0.64 & 0.90 & 0.41 & 2.56 & 75.1 & 82.5 & 18.7 & 15.4 \\
\hline Convention & Inorganic & 6.13 & 6.79 & 19.5 & 26.0 & 0.64 & 0.72 & 0.32 & 2.36 & 74.6 & 94.0 & 18.9 & 14.8 \\
\hline Convention & No-fertilizer & 6.10 & 6.68 & 19.0 & 13.5 & 0.67 & 0.73 & 0.41 & 2.22 & 78.2 & 65.5 & 19.7 & 14.5 \\
\hline \multicolumn{2}{|c|}{ Irrigation } & $\mathrm{ns}$ & ns & $\mathrm{ns}$ & ns & $\mathrm{ns}$ & ns & $\mathrm{ns}$ & $*$ & $\mathrm{~ns}$ & ns & $\mathrm{ns}$ & $*$ \\
\hline \multicolumn{2}{|c|}{ Fertilizer } & ns & $*$ & $\mathrm{~ns}$ & $* *$ & * & $*$ & $*$ & $*$ & $*$ & $*$ & $*$ & $*$ \\
\hline \multicolumn{2}{|c|}{ Irrigation $\times$ Fertilizer } & ns & ns & ns & $*$ & ns & ns & $*$ & ns & ns & ns & ns & $\mathrm{ns}$ \\
\hline
\end{tabular}

Note: According to ANOVA, there was no significance(ns) at $\mathrm{P}>0.05$ and significant differences $(*)$ at $\mathrm{P} \leq 0.05$, while there was extremely significant difference $(* *)$ at $\mathrm{P} \leq 0.01$ at $\alpha=0.05$ level. 
$92.2 \mathrm{mg} \mathrm{kg}^{-1}$ in inorganic fertilizer treatment. We can conclude that soil-hydrolyzed nitrogen concentration was mainly coming from inorganic fertilizer. The interaction between irrigation and fertilizer showed no significance.

Moreover, available phosphorus concentration decreased in all treatments after rice harvest. In two irrigation treatments, it showed the same pattern of decrement combined $>$ inorganic $>$ no-fertilizer. This illustrated that organic fertilizer can supply soil-available phosphorus, and thus delayed a decrease in available phosphorus concentration. The interaction between irrigation and fertilizer showed no significance.

\section{Change in Nitrogen Concentration in Field Surface Water}

Panicle fertilizer was applied on August 19, 2013. Then it rained continuously during the following week, which formed a typical pollutant transport process in a rain event. Since the applied fertilizer was urea, we studied changes in total nitrogen (TN), ammonium nitrogen $\left(\mathrm{NH}_{3}-\mathrm{N}\right)$, and nitrate nitrogen $(\mathrm{NO}-\mathrm{N})$ concentrations in field surface water after fertilization and obtained the results as shown in Fig. 1 to Fig. 3.

TN concentration in treatments $\mathrm{S} 1$ and $\mathrm{S} 2$ reached its maximum value one day after fertilization and then decreased with time afterward (Fig. 1). TN did not change much in treatment S3. Generally speaking, the curve shape for $\mathrm{S} 1$ was convex, while it was concave for $\mathrm{S} 2$.

In treatment $\mathrm{S} 1$, TN concentration decreased gently during the first three days, and it decreased sharply thereafter (Fig. 1). Overall, the TN concentration was decreased by $75.0 \%$ and $82.2 \%$ for $\mathrm{T} 1 \mathrm{~S} 1$ and $\mathrm{T} 2 \mathrm{~S} 1$, respectively. In treatment $\mathrm{S} 2$, the $\mathrm{TN}$ concentration sharply decreased at first, and then gradually decreased to a lower level than that in treatment $\mathrm{S} 1$. Then it stayed rather stable (Fig. 1). Overall, the TN concentration decreased by $80.3 \%$ and $83.5 \%$ for T1S2 and T2S2, respectively.

At the beginning, $\mathrm{TN}$ concentration in $\mathrm{S} 1$ was lower than that in S2 because of the quick-release feature of inorganic fertilizer. Then, due to the slow-release trends of organic fertilizer, TN concentration in S1 maintained at a high level in the surface water. Then TN concentration decreased sharply thereafter because the organic fertilizer was quickly drained out. TN concentration in $\mathrm{T} 1$ was lower than that in $\mathrm{T} 2$ at first because the water layer in the controlled irrigation was lower than that in conventional irrigation. Therefore, it was concluded that the controlled irrigation condition was favorable for organic fertilizer release.

The decreases in TN concentration were mainly due to absorption by rice plants and migration and transformation of nitrogen itself. Thus, the main period to control nitrogen loss was within one week after urea application in this rice growth period.

In $\mathrm{S} 3$, the $\mathrm{TN}$ concentration slightly changed during the measurement period. It was consistent with the fact that no fertilizer was applied.

The changing trend in $\mathrm{NH}_{3}-\mathrm{N}$ concentration after a rain event was similar to $\mathrm{TN}$, with the maximum concentration one day after fertilization and then steady decreases with time afterward (Fig. 2). Overall, the $\mathrm{NH}_{3}-\mathrm{N}$ concentration decreased by $89.7 \%, 97.8,91.4 \%$, and $96.6 \%$, for T1S1, T2S1, T1S2, and T2S2 treatments, respectively, within 10 days.

The curve shape was an "S" type for $\mathrm{S} 1$, while it was concave for $\mathrm{S} 2$. In treatment $\mathrm{S} 2$, the decrease was much greater than that in treatment $\mathrm{S} 1$ at first, and it was the same reason as shown in $\mathrm{TN}$ above. Then they steadily decreased with time afterward. However, $\mathrm{NH}_{3}-\mathrm{N}$

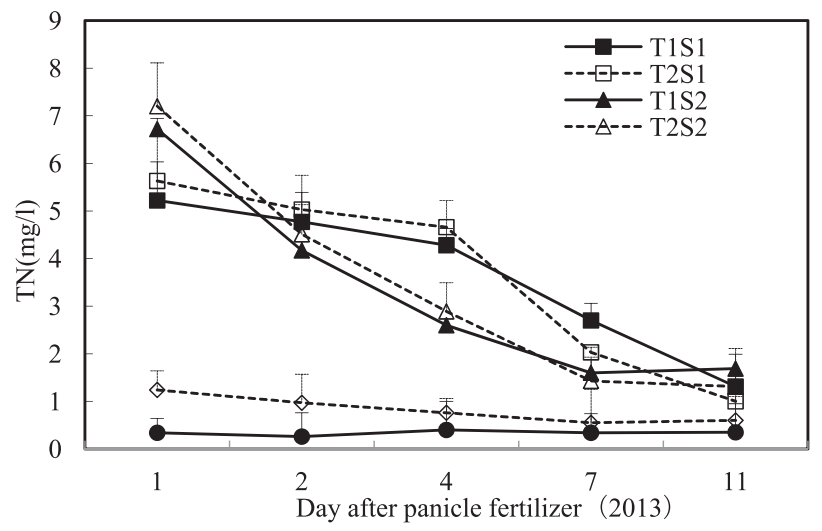

Fig. 1. TN concentration change curve in field surface water.

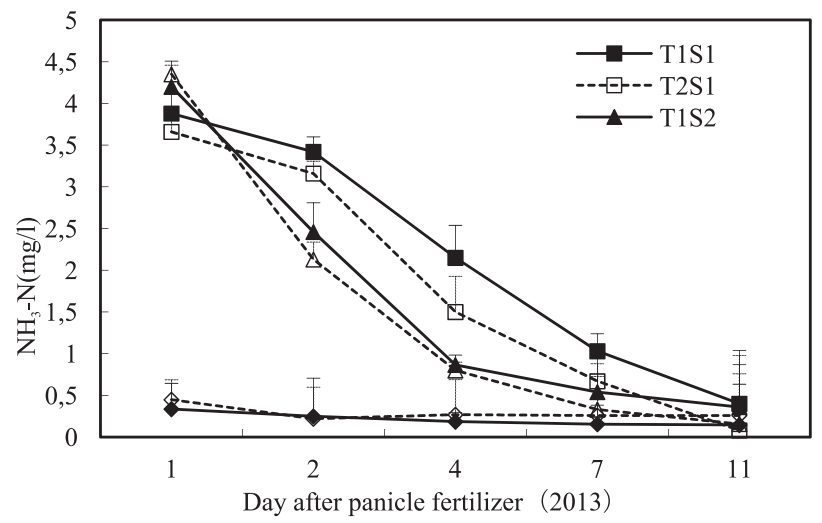

Fig. 2. $\mathrm{NH}_{3}-\mathrm{N}$ concentration change curve in field surface water.

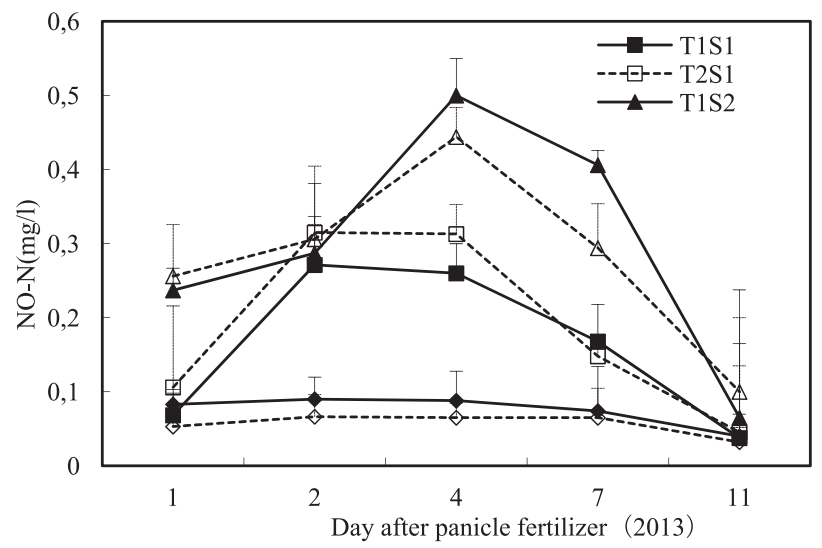

Fig. 3. NO-N concentration change curve in field surface water. 
concentration in treatment S1 decreased more sharply than in treatment S2. Eventually almost reaching the same level.

In $\mathrm{S} 3$, the $\mathrm{NH}_{3}-\mathrm{N}$ concentration slightly changed during the measuring period. It was consistent with the fact that no fertilizer was applied.

The changing curve of NO-N concentration showed a very different trend from $\mathrm{TN}$ and $\mathrm{NH}_{3}-\mathrm{N}$ (Fig. 3). The concentration curve shaped like a bell for treatment $\mathrm{S} 1$, while it showed a similar pattern with a little bit of irregular boundary. The concentration all increased during the first two days and then treatment S2 maintained while increasing more quickly than before, while the S1 treatment was almost the same. In treatment S1, NO-N concentration reached peak two days after fertilization, while in treatment $\mathrm{S} 2$, NO-N concentration reached its peak four days after fertilization. This was because NO-N was translated from $\mathrm{NH}_{3}-\mathrm{N}$ through nitration reaction, and this process was related to soil temperature and decomposition time, and thus the peak time was later than $\mathrm{NH}_{3}-\mathrm{N}$. After that, they all decreased to a lower level, with more sharply decreasing in treatment S2 and gradually decreasing in treatment $\mathrm{S} 1$, which was just opposite changes in $\mathrm{NH}_{3}-\mathrm{N}$ concentration. Overall, $\mathrm{NH}_{3}-\mathrm{N}$ concentration and NO-N concentration in treatment $\mathrm{S} 3$ did not change much during the measuring period.

\section{Pollution Discharge in Drainwater after Fertilization}

After the rain, drainage occurred through the drainage pipe in the paddy field. The discharge was measured by water meter and then converted to water depth over the field. Since the paddy field drainage was a continuous process and pollutant concentration in discharge varied with time, the pollution discharge amount was only estimated with the average discharge and instant pollutant concentration. The estimated pollutant discharges are shown in Table 3.

As shown in Table 3, the total discharge was $95 \mathrm{~mm}$ for controlled irrigation while it was $120 \mathrm{~mm}$ for the conventional irrigation regime. Thus, under the controlled irrigation water conditions, more water can be retained in a paddy field. Less water discharge resulted in less pollutant amount, which was favorable for water body environment protection.

$\mathrm{NH}_{3}-\mathrm{N}$ was the main form of nitrogen loss in drainage, while NO-N concentration was very low to negligible. By excluding no fertilizer treatment, the results showed that the averaged pollutant discharge amount changed greatly for different irrigation regimes. However, fertilizer treatments did not show a big difference. With total nitrogen as an example, averaged TN discharge amount in conventional irrigation was $36.7 \%$ more than that in controlled irrigation, while the averaged TN discharge amount in two fertilizer treatments did not vary much, with $8.4 \%$ less in organic + inorganic fertilizer treatment than in inorganic fertilizer treatment. In conclusion, the combination of organic fertilizer with controlled irrigation was favorable for pollution reduction and environmental protection.

According to the variance homogeneity of ANOVA and ANOVA analysis, the fertilizer effect was significant to $\mathrm{TN}$ and $\mathrm{NH}_{3}-\mathrm{N}$ concentrations, whereas it was no significance to total $\mathrm{TN}$ and $\mathrm{NH}_{3}-\mathrm{N}$ discharge. As for irrigation effect, there was no significance to $\mathrm{TN}$ and $\mathrm{NH}_{3}-\mathrm{N}$ concentrations and discharge. As for NO-N, the fertilizer and irrigation effects were the same for both drainage processes. The fertilizer showed significance for both the concentration and total discharge, while the irrigation showed no significance for NO-N concentration and total discharge. That was due to low NO-N content

Table 3. Estimated pollution discharge amount in each treatment.

\begin{tabular}{|c|c|c|c|c|c|c|c|}
\hline \multirow[b]{2}{*}{ Treatment } & \multirow{2}{*}{$\begin{array}{c}\text { Discharge } \\
(\mathrm{mm})\end{array}$} & \multicolumn{2}{|c|}{$\mathrm{TN}$} & \multicolumn{2}{|c|}{$\mathrm{NH}_{3}-\mathrm{N}$} & \multicolumn{2}{|c|}{$\mathrm{NO}-\mathrm{N}$} \\
\hline & & $\begin{array}{c}\mathrm{CN} \\
\left(\mathrm{mg} \mathrm{l}^{-1}\right)\end{array}$ & $\begin{array}{c}\text { TPD } \\
\left(\mathrm{kg} \mathrm{hm}^{-2}\right)\end{array}$ & $\begin{array}{c}\mathrm{CN} \\
\left(\mathrm{mg} \mathrm{l}^{-1}\right)\end{array}$ & $\begin{array}{c}\text { TPD } \\
\left(\mathrm{kg} \mathrm{hm}^{-2}\right)\end{array}$ & $\begin{array}{c}\mathrm{CN} \\
\left(\mathrm{mg} \mathrm{l}^{-1}\right)\end{array}$ & $\begin{array}{c}\text { TPD } \\
\left(\mathrm{kg} \mathrm{hm}^{-2}\right)\end{array}$ \\
\hline T1S1 & 95 & $4.1 \mathrm{a}$ & $3.9 \mathrm{a}$ & $4.01 \mathrm{a}$ & $3.81 \mathrm{a}$ & $0.006 \mathrm{a}$ & $0.0057 \mathrm{ab}$ \\
\hline T2S1 & 120 & $4.2 \mathrm{ab}$ & $5.04 \mathrm{a}$ & $4.07 \mathrm{a}$ & $4.88 \mathrm{ab}$ & $0.006 \mathrm{a}$ & $0.0072 \mathrm{a}$ \\
\hline T1S2 & 95 & $4.2 b$ & $3.99 \mathrm{ab}$ & $3.90 \mathrm{~b}$ & $3.71 \mathrm{a}$ & $0.006 \mathrm{~b}$ & $0.0057 b$ \\
\hline $\mathrm{T} 2 \mathrm{~S} 2$ & 120 & $4.8 \mathrm{bc}$ & $5.76 \mathrm{a}$ & $4.62 b$ & $5.54 \mathrm{a}$ & $0.007 \mathrm{~b}$ & $0.0084 b c$ \\
\hline T1S3 & 95 & $2.3 \mathrm{c}$ & $2.19 \mathrm{ab}$ & $2.22 \mathrm{c}$ & $2.11 \mathrm{ab}$ & $0.001 \mathrm{ac}$ & $0.0010 \mathrm{c}$ \\
\hline T2S3 & 120 & $2.1 \mathrm{c}$ & $2.52 \mathrm{ab}$ & $2.05 b c$ & $2.46 \mathrm{a}$ & $0.002 \mathrm{c}$ & $0.0024 \mathrm{c}$ \\
\hline Irrigation & & ns & ns & ns & ns & ns & ns \\
\hline Fertilizer & & $*$ & ns & $*$ & ns & $*$ & $*$ \\
\hline Irrigation $\times$ Fertilizer & & ns & ns & ns & ns & ns & ns \\
\hline
\end{tabular}

Notes: 1) CN is short for concentration, and TPD is short for total pollution discharge; 2) According to ANOVA, there was no significance (NS) at $\mathrm{P}>0.05$ and significant differences $(*)$ at $\mathrm{P} \leq 0.05$, while there was extremely significant difference $(* *)$ at $\mathrm{P} \leq 0.01$ at $\alpha=0.05$ level; and 3 ) there is no change between the same letters (a, b, or c). 
Table 4. Rice yield and its composition in each treatment.

\begin{tabular}{|c|c|c|c|c|c|}
\hline \multirow[b]{2}{*}{ Treatment } & \multicolumn{3}{|c|}{ Yield Composition } & \multirow{2}{*}{$\begin{array}{l}\text { Theoretical Yield } \\
\qquad\left(\mathrm{kg} \mathrm{hm}^{-2}\right)\end{array}$} & \multirow{2}{*}{$\begin{array}{l}\text { Grain Yield } \\
\left(\mathrm{kg} \mathrm{hm}^{-2}\right)\end{array}$} \\
\hline & $\begin{array}{c}\text { Productive } \\
\text { Panicles }\left(\mathrm{m}^{-2}\right)\end{array}$ & $\begin{array}{l}\text { Total Grains per } \\
\text { Panicle }\end{array}$ & $\begin{array}{c}\text { Thousand-grain Weight } \\
\left(\mathrm{g} 1000^{-1}\right)\end{array}$ & & \\
\hline T1S1 & 222 & 152.8 & 26.97 & 9148.7 & $8876.5 \mathrm{Ac}$ \\
\hline$T 2 S 1$ & 255 & 135.8 & 26.38 & 9135.1 & $8823.8 \mathrm{Ac}$ \\
\hline T1S2 & 212 & 120.6 & 24.20 & 6187.3 & $6024.5 \mathrm{Ab}$ \\
\hline T2S2 & 182 & 140.2 & 27.13 & 6922.6 & $6535.0 \mathrm{Aab}$ \\
\hline T1S3 & 176 & 77.2 & 27.46 & 3731.0 & $3566.7 \mathrm{Aa}$ \\
\hline T2S3 & 153 & 77.6 & 24.85 & 2950.4 & $3024.9 \mathrm{Aab}$ \\
\hline Irrigation & ns & $\mathrm{ns}$ & ns & ns & ns \\
\hline Fertiizer & $*$ & $*$ & ns & $* *$ & $*$ \\
\hline Irrigation $\times$ Fertilizer & $\mathrm{ns}$ & $*$ & ns & $*$ & $*$ \\
\hline
\end{tabular}

Notes: 1) According to ANOVA, there was no significance (ns) at $\mathrm{P}>0.05$ and significant differences $(*)$ at $\mathrm{P} \leq 0.05$, while there was extremely significant difference $(* *)$ at $\mathrm{P} \leq 0.01$ at $\alpha=0.05$ level; and 2 ) for the same fertilizer, different irrigation condition effects on yield are shown by capital letters (A or B), while for the same irrigation, different fertilizer condition effects on yield are shown by lowercase letters $(\mathrm{a}, \mathrm{b}$, or $\mathrm{c})$.

in the discharge. The interaction between irrigation and fertilizer all showed no significance on three forms of nitrogen concentration and discharge.

\section{Effects on Rice Yield}

The main rice yield composition indicators are panicle number per $\mathrm{m}^{2}$, total grains per panache (TGP) and thousand-grain weight (TGW). This project focused on the effects of different fertilizer and irrigation regimes on rice yield and controlling factors.

As shown in Table 4 under S1, TI had a lower productive panicle number, but higher total TGP and a bit higher TGW, resulting in almost identical yield in comparison with T2. Under S2, T1 had higher apanicle number, but lower TGP and TGW, resulting lower yield than T2. Under S3, T1 had a higher panicle number, almost identical TGP and higher TGW, resulting in a higher yield than $\mathrm{T} 2$.

Under organic fertilizer conditions, panicle numbers can increase significantly according to analysis of variance. The productive panicle numbers per $\mathrm{m}^{2}$ were 238.5 (for $\mathrm{S} 1)>197(\mathrm{~S} 2)>164.5(\mathrm{~S} 3)$. For water condition effect, the productive panicle numbers per $\mathrm{m}^{2}$ were 203.3 (for T1) > 196.7 (T2). There was no significant change under different water conditions, and the water and fertilizer interaction played no significant role on productive panicles. Also, the water effect on TGP and TGW was not significant. The changes among different fertilizer conditions on TGP were significant and on TGW were not. Thus through the effect on productive panicles per $\mathrm{m}^{2}$ and TGP rather than TGW, fertilizer conditions showed extreme difference on paddy rice yield. Since all the factors under two water conditions were not significant, irrigation regimes showed no significance on rice yield.
However, the interaction between irrigation regimes and fertilizers was significant.

It was obvious that fertilizer factors played a rather more important role than water factors in rice yield formation. Rice yield increased $2,588.3 \mathrm{~kg} \mathrm{hm}^{-2}$ by organic fertilizer addition to inorganic fertilizers, compared with traditional chemical fertilizer application only with a yield increasing rate up to $39.47 \%$. The reason for this result was mainly because only an inorganic fertilizer application may result in deficiencies of micro-elements such as $\mathrm{Mg}, \mathrm{S}$, and $\mathrm{Zn}$ in soil, while organic fertilizer-supplied micro-elements directly in addition to regulations of nutrients release intensity and velocity.

Theoretical rice yield was calculated through formula (1), while actual yield was recorded from each experimental plot. Adequate correlations were found between the theoretical and actual yield for all six treatments. Linear equation ( $\mathrm{y}=0.9519 \mathrm{x}+101.21)$ was fitted well using statistical regression. The $\mathrm{R}^{2}$ value was 0.9984 , showing a strong correlation.

$$
Y=M \times N \times P / 100
$$

... where $Y$ is theoretical rice yield, $\mathrm{kg} \mathrm{hm}^{-2} ; M$ is productive panicles, $\mathrm{m}^{-2} ; N$ is total grains per panicle; and $P$ is TGWs, g per 1,000 kernels.

\section{Summary}

Based on the field experiment and lab analysis, the following summaries can be made:

1. Soil $\mathrm{pH}$ and organic matter concentration in all fertilized treatments increased after rice harvest, and organic fertilizer can help soil stay in a rather neutral environment. In addition, the water conditions in controlled irrigation helped more organic matters be 
retained in the soil, which results in high rice yield.

2. Soil total nitrogen and total phosphorus concentration increased after rice harvest. Hydrolysis nitrogen concentration in fertilized treatments showed the trend of increasing, while in no fertilizer treatments did it decline. As for available phosphorus concentration, it decreased in all treatments after rice harvest.

3. After a typical rain event, the total nitrogen concentration reached peak one day after fertilization, and then decreased with time in fertilized treatments, while in no fertilizer treatments did it change much. The changing trends of ammonium nitrogen concentration were similar to total nitrogen. Nitrate nitrogen concentration showed the trend of increasing first and then decreasing, except in no fertilizer treatments, and the change curve also was different. Generally speaking, the concentration change curve shape was determined by fertilizer condition.

4. During the surface drainage process, ammonium nitrogen was the main form of nitrogen loss while nitrate nitrogen was negligible. The pollutant discharge amount showed large differences among irrigation regimes. The combination of organic fertilizer to controlled irrigation can reduce pollution concentration to some extent compared to other treatments.

5. Fertilizer conditions showed extreme significance on paddy rice yield through the effect on panicle numbers per $\mathrm{m}^{2}$ and grain numbers per ear rather than thousand-grain weight. Water and fertilizer conditions all showed no significance on TGW. The differences in paddy rice yield among fertilizers were extremely significant, while there was no significant difference between two irrigation regimes. The interaction between irrigation regimes and fertilizers was also significant. The significance of organic fertilizer effect on rice yield was more obvious than water condition effect. The interaction between irrigation regimes and fertilizers on rice yield was significant. Finally, organic fertilizer combined with inorganic fertilizer increased rice yield by $39.47 \%$.

\section{Limitations}

Since this research was conducted on a natural paddy field, soil conditions were not exactly uniform at the beginning. Such variations may affect experiment results. For future experiments the soil should be prepared as uniformly as possible to avoid such impacts.

It is also important to note that the above results were only based on data of the one-year experiment. However, the organic fertilizer effect on both yield and environment may take longer to exhibit. Hence, further extended studies are recommended to account for long-term effects.

\section{Conclusion}

The combined application of organic and inorganic fertilizers improved soil system productivity, especially under controlled irrigation regimes, with high water conservation potential, the high-yield increasing effect, and less pollution impact. In conclusion, this management was feasible in paddy rice production in south China. Further detailed studies are needed to elucidate how the organic fertilizer affects rice yield through its effect on soil physical and chemical properties.

\section{Acknowledgements}

This work was funded in part by the Research Project of Special Scientific Funds in Public Service Sectors (Water Conservancy) (201301017), the Fundamental Research Funds for the Central Universities (2014B37714, 2014B04814, 2015B05814), Science and Technology Project of Jiangsu Province (BE2015705), and Water Conservancy Science and Technology Project of Jiangsu Province $(2013073,2014049)$. Also, the first author has special thanks to her advisors, Dr. Zhu-ping Sheng at Texas A\&M AgriLife Research Center and Dr. Hui-lian $\mathrm{Xu}$ at International Nature Farming Research Center for their efforts in improvements of the manuscript. We are also thankful to anonymous reviewers and the editor for their valuable review comments and suggestions.

\section{References}

1. LIAO X.Y., CHEN Q.G., PANG Q.L. Production status and development strategies of high quality rice in China. J. Agrotech. Eco., 5, 32-34, 2002.

2. TESFAYE S.G., ISMAI M.R., KAUSAR H., MARZIAH M., RAMLAN M.F. Plant water relations, crop yield and quality of Arabica Coffee as affected by supplemental deficit irrigation. International J. Agr. Biol., 15 (4), 665, 2013.

3. WANG Y., PENG S.Z., JIAO J., KONG W.L. Research on nitrogen dynamics in paddy field under different levels of water and fertilizer during whole growing period. Water Sav. Irri., 9, 12, 2009.

4. ZHU Z.L. Nitrogen management in relation to food production and environment in China. Acta Pedologica Sin., 39 (supplement), 3, 2002.

5. LIU Y.R., LI X., YU J., SHEN Q.R., XU Y.C. Mechanisms for the increased fertilizer nitrogen use efficiency of rice in wheat-rice rotation system under combined application of inorganic and organic fertilizers. Chinese J. Appli. Eco., 23 (1), 81, 2012.

6. BANDYOPADHYAY K.K., MISRA A.K., GHOSH P.K. HATI K.M. Effect of integrated use of farmyard manure and chemical fertilizers on soil physical properties and productivity of soybean. Soil Till. Res. 110, 115, 2010.

7. ZHANG X.L., MENG L., WANG Q.J., LUO J, HUANG Q.W., XU Y.C., YANG X.M. SHEN Q.R. Effects of organicinorganic mixed fertilizers on rice yield and nitrogen use efficiency. Chinese J. Appli. Ecol., 20 (3), 624, 2009.

8. WANG X.D., ZHANG Y.P., LV J.L., FAN X.L. Effect of long term different fertilization on properties of soil organic matter and humic acids. Sci. Agr. Sin., 33 (2), 75, 2000.

9. SUI Y.Y., ZHANG X.Y., JIAO X.G., WANG Q.C., ZHAO J. Effect of long-term different fertilizer applications on organic matter and nitrogen of black farmland. J. Soil Water Conserv., 19 (6), 190, 2005. 
10. FARHAD W., CHEEMAM.A., SALEEM M.F., RADOVICH T., FARHAT A., HAMMAD H.M., WAHID M.A. Yield and quality response of maize hybrids to composted poultry manure at three irrigation levels. J Agr. Biol., 15 (2), 181, 2013.

11. LIU S.Y., DONG X., ZHU S.X., HAN G.H., WEI D.J. Effects of different application portions of organic and chemical fertilizers on rice yield in areas along the Yellow River. Shandong Agr. Sci., 45 (8), 90, 2013.

12. HOU H.Q., LIU X.M., LIU G.R., ZHANG L.Z., HUANG Y.L., JI J.H., SHAO C.H., WANG F.Q. Effect of long-term located organic-inorganic fertilizer application on rice yield and soil fertility in red soil area of China. Sci. Agr. Sin., 44 (3), 516, 2011.

13. TIWARI A., DWIVEDI A.K., DIKSHIT P.R. Longterm influence of organic and inorganic fertilization on soil fertility and productivity of soybean-wheat system in a Vertisol. J. Ind. Soc. Soil Sci., 50, 472, 2002.

14. EDMEADES D.C. The long-term effects of manures and fertilizers on soil productivity and quality: A review. Nutr. Cyc. Agroecosys., 66, 165, 2003.

15. VELTHOF G.L., KUIKMAN P.J., OENEMA O. Nitrous oxide emission from animal manures applied to soil under controlled conditions. Biol. Fert. Soils., 37, 221, 2003.

16. JONES S.K., REES R.M., SKIBA U.M., BALL B.C. Influence of organic and mineral $\mathrm{N}$ fertiliser on $\mathrm{N}_{2} \mathrm{O}$ fluxes from a temperate grassland. Agric. Ecosys. Environ., 121, 74, 2007.

17. RAHMAN M.H., ISLAM M.R., JAHIRUDDIN M., PUTEH A.B., MONDAL M.M.A. Influence of organic matter on nitrogen mineralization pattern in soils under different moisture regimes. J. Agr. Biol., 15 (1), 55, 2013.

18. CAI Z.J., SUN N., WANG B.R., XU M.G., HUANG J., ZHANG H.M. Effects of long-term fertilization on $\mathrm{pH}$ of red soil, crop yields and uptakes of nitrogen, phosphorus and potassium. Plant Nutr. Fert. Sci., 17 (1), 71, 2011.

19. DING Y.M., LI H.G., HE J.X., WANG Y.J., LU Q.H., ZHOU X.G., ZHANG S.S. Effects of combined application of organic manure and compound chemical fertilizer on soil $\mathrm{pH}$ value of tobacco rhizosphere. Southwest China J. Agr. Sci., 24 (2), 635, 2011.

20. ZHANG J.B., YANG J.S., YAO R.J., YU S.P., LI F.R., HOU X.J., JIN W.H., WANG X.P. Dynamics of soil water, salt and crop growth under farmyard manure and mulching in coastal tidal flat soil of Northern Jiangsu Province. Transl. Chinese Soc. Agr. Eng., 29 (15), 116, 2013.

21. AYOOLA O.T., MAKINDE E.A. Complementary organic and inorganic fertilizer application: Influence on growth and yield of Cassva/maize/melon intercrop with a relayed cowpea. Aust. J. Basic Appl. Sci., 1, 187, 2007.

22. XU M.G., LI D.C., LI J.M., QIN D.Z., KAZUYUKI Y., YASUKAZU H. Effects of organic manure application combined with chemical fertilizers on nutrients absorption and yield of rice in Hunan of China. Sci. Agr. Sin., 41 (10), 3133, 2008.

23. ZHOU W.J., WANG K.R., ZHANG G.Y. XIE X.L. Effects of inorganic-organic fertilizer incorporation on productivity and soil fertility of rice cropping system in red soil area of China. Sci. Agr. Sin., 35 (9), 1109, 2002.

24. KAUR T., BRAR B.S., DHILLON N.S. Soil organic matter dynamics as affected by long-term use of organic and inorganic fertilizers under maize-wheat cropping system. Nutr. Cyc. Agroecosys., 10, 110, 2007.

25. LI Y.Y., SHAO X.H., TAN J.Y., HU X.J., ZHOU J., WANG J.L., LU S.G., XU H.L. Effects of different irrigation regimes and fertilizer on paddy rice chlorophyll content and leaf area index. Adv. Biomed. Eng., APEST 2012, 6, 527, 2012a.

26. LI Y.Y., SHAO X.H., TAN J.Y., HU X.J., ZHOU J., WANG J.L., LU S.G. Effects of controlled and mid-gathering irrigation on paddy rice height and yield. J. Food, Agr. Environ., 10 (3-4), 659, 2012b.

27. LI Y.Y., SHAO X.H., SHENG Z.P. Field experiments on reducing pollutants in agricultural-drained water using soilvegetation buffer strips. Pol. J. Environ. Stud., 25 (1), 183, 2016.

28. Agricultural Chemistry Committee of Soil Science Society of China. Analytical methods for soil agricultural chemistry. Beijing: China Science Press, 241, 1983.

29. BAO S.D. Soil and agricultural chemistry analysis (The Third Edition). Beijing: China Agriculture Press, 30, 2000.

30. State Environmental Protection Association. Water and wastewater monitoring analysis method (The Fourth Edition). Beijing: China Environmental Science Press, 244, 2002.

31. DUNCAN D.B. Multiple range and multiple $\mathrm{F}$ tests. Biometrics, 11, 1, 1955. 